\title{
PENGARUH KONSENTRASI SUKROSA TERHADAP KARAKTERISTIK MINUMAN PROBIOTIK SARI BUAH TERUNG BELANDA TERFERMENTASI DENGAN LACTOBACILLUS RHAMNOSUS SKG34
}

The Effects of Sucrose Concentration on Characteristics of Fermented Tamarillo Probiotic Juice with Lactobacillus rhamnosus SKG34

\author{
${ }^{1}$ Netta Clarita Tampinongkol, ${ }^{2}$ Komang Ayu Nocianitri*, ${ }^{2}$ I Gusti Ayu Ekawati \\ ${ }^{1}$ Mahasiswa Program Studi Ilmu dan Teknologi Pangan, Fakultas Teknologi Pertanian, Universitas Udayana \\ ${ }^{2}$ Dosen Program Studi Ilmu dan Teknologi Pangan, Fakultas Teknologi Pertanian, Universitas Udayana \\ Kampus Bukit Jimbaran, Badung-Bali
}

\begin{abstract}
This research was conducted to determine the effects of sucrose concentration on characteristics of fermented tamarillo (Solanum betaceum Cav.) probiotic juice with L. rhamnosus SKG34. The Randomized Block Design was used with 5 treatment of sucrose concentration such as $(0 \%, 3 \%, 6 \%, 9 \%$, and $12 \%)$. The treatment was repeated 3 times so that were obtained 15 experimental units. Data were analyzed by ANOVA and DNMRT Test. The parameters observed included total LAB, total sugar, total acid, $\mathrm{pH}$, and sensory acceptance of the resulting product were analyzed by a hedonic test on color, aroma, taste, and scoring test on color, as well as sourness and sweetness of the product, and overall acceptance. The results showed that the treatment of sucrose concentration on fermented tamarillo probiotic juice significantly affected the total LAB, total sugar, total acid, $\mathrm{pH}$, color (score), taste (hedonic), sour taste and sweet taste (score), and overall acceptance, but no significant effect on color (hedonic) and aroma. The concentration of $9 \%$ sucrose produced the best characteristics of fermented tamarillo probiotic juice with total LAB $1.30 \times 10^{9} \mathrm{cfu} / \mathrm{ml}$, total sugar $12.69 \%$, total acid $3.08 \%$, pH 3.61, the red color was preferred, the flavor slightly liked, the taste slightly sour and sweet was slightly preferred, and overall acceptance was preferred.
\end{abstract}

Keywords: tamarillo, juice, probiotic, sucrose, Lactobacillus rhamnosus SKG34.

\section{PENDAHULUAN}

Seiring dengan meningkatnya kesadaran masyarakat akan pentingnya pengaruh pangan fungsional bagi kesehatan, produk pangan fermentasi berkembang dengan pesat (Sintasari et al., 2014). Salah satu produk pangan fungsional adalah minuman probiotik. Minuman probiotik merupakan minuman yang mengandung bakteri asam laktat (BAL) (FAO/WHO, 2001) dan mempunyai efek menguntungkan pada inang (host) untuk memperbaiki keseimbangan mikroba intestinal (Fuller, 1989). Salah satu BAL yang menghasilkan metabolit berupa asam laktat, yaitu Lactobacillus rhamnosus SKG34. L. rhamnosus SKG34 termasuk BAL homofermentatif yang diisolasi dari susu kuda Sumbawa dan dapat digunakan sebagai kultur fungisonal probiotik (Sujaya et al., 2008). Salah satu media yang dapat menjadi alternatif pertumbuhan BAL adalah minuman sari buah. Saat ini telah banyak dilakukan penelitian pembuatan minuman probiotik berbahan baku sari buah, seperti minuman probiotik sari buah kurma (Retnowati dan Kusnadi, 2014), minuman probiotik sari buah nanas (Rizal et al., 2016), dan minuman probiotik sari buah jambu biji merah (Nurainy et al., 2018). Terung belanda (Solanum betaceum Cav.) memiliki nutrisi yang dibutuhkan oleh tubuh seperti vitamin C, mineral, beta karoten, karbohidrat, protein, lemak, dan serat, serta memiliki aroma yang khas (Kumalaningsih dan Suprayogi, 2006). Terung belanda merupakan subsrat yang baik karena mengandung karbohirat sebagai sumber karbon bagi pertumbuhan Lactobacillus sp. F213 pada minuman sari buah terung belanda selama penyimpanan dingin, dimana viabilitas probiotik tersebut stabil hingga hari ke-12 dengan populasi $10^{6}$

*Korespondensi Penulis: 
cfu/ml (Rini, 2019). Pemanfaatan terung belanda masih belum maksimal padahal buah ini berpotensi dikembangkan menjadi minuman probiotik. Syarat karakteristik minuman probiotik harus memiliki bakteri probiotik jumlah minimal sebanyak $10^{7}$ $\mathrm{cfu} / \mathrm{ml}$ bakteri probiotik sehingga dengan difermentasi dapat mempertahankan jumlah populasi probiotik.

Salah satu faktor yang mempengaruhi pertumbuhan BAL dalam proses fermentasi adalah sumber karbon (gula). Sukrosa adalah sumber energi dan karbon bagi pertumbuhan BAL. Penambahan sukrosa pada minuman probiotik sari buah terung belanda terfermentasi dapat menunjang pertumbuhan BAL dan diharapkan meningkatkan viabilitas mikroba dan citarasa produk (Hartati, et al., 2012). Namun, penambahan sukrosa ke dalam minuman probiotik harus dengan jumlah yang tepat untuk menghasilkan minuman dengan jumlah bakteri yang mencukupi minimal $10^{6}$ $\mathrm{cfu} / \mathrm{ml}$ dengan karakteristik yang baik. Penambahan sukrosa $12 \%$ menghasilkan karakteristik terbaik pada minuman probiotik sari kulit nanas (Elsaputra et al., 2016) dan minuman probiotik sari tomat (Harahap et al., 2018), sedangkan pada minuman probiotik sari jambu biji merah menghasilkan karakteristik terbaik dengan penambahan sukrosa 4\% (Nurainy et al., 2018). Pada penelitian ini, belum diketauhi berapa penambahan sukrosa yang dapat menunjang pertumbuhan L. rhamnosus SKG34 dalam minuman probiotik sari buah terung belanda terfermentasi agar menghasilkan karakteristik terbaik, yaitu total BAL yang mencukupi dan nilai sensoris yang disukai. Oleh karena itu, perlu dilakukan penelitian mengenai pengaruh penambahan sukrosa dengan tujuan mengetauhi pengaruh konsentrasi sukrosa terhadap karakteristik minuman probiotik sari buah terung belanda terfermentasi dan mengetauhi konsentrasi sukrosa yang paling tepat untuk menghasilkan karakteristik minuman probiotik sari buah terung belanda terfermentasi terbaik sebagai minuman probiotik yang baik bagi kesehatan tubuh.

\section{METODE PENELITIAN}

\section{Tempat dan Waktu}

Penelitian ini dilaksanakan di UPT. Laboratorium Terpadu Biosains dan Bioteknologi Universitas Udayana, Laboratorium Biokimia dan Nutrisi Fakultas Teknologi Pertanian, dan Laboratorium Rekayasa Proses dan Pengendalian Mutu Fakultas Teknologi Pertanian, Jl. Raya Kampus Udayana, Bukit Jimbaran. Pelaksanaan penelitian ini dilakukan pada bulan Juni hingga Agustus 2019.

\section{Bahan dan Alat}

Bahan yang digunakan dalam penelitian ini adalah isolat $L$. rhamnosus SKG34 (koleksi UPT Laboraturium Terpadu Biosains dan Bioteknologi Universitas Udayana), buah terung Belanda (dibeli di Pasar Kidul, Bangli), sukrosa (Gulaku), air mineral, alkohol 96\%, metanol, de Man Rogosa and Sharpe Agar/MRSA (Oxoid), de Man Rogosa and Sharpe Broth/MRSB (Oxoid), akuades, $\mathrm{NaCl} 0,85 \%$, gliserol, kristal violet, larutan lugol, pewarna safranin, pereaksi anthrone (Merck), $\mathrm{H}_{2} \mathrm{SO}_{4}$ pekat, phenolphthalein (PP) 1\%, glukosa standar, larutan buffer $\mathrm{pH} 4$ dan 7 , larutan $\mathrm{H}_{2} \mathrm{O}_{2}$, $\mathrm{NaOH} 0,0952 \mathrm{~N}, \mathrm{HCl} 4 \mathrm{~N}$, alumunium foil, plastik dan tisu.

Alat yang digunakan dalam penelitian ini adalah jar, botol plastik, baskom, pisau, talenan, kain saring, kulkas, juicer extractor, freezer, cawan petri (Petriq), tabung reaksi (pyrex), jarum ose, inkubator, laminar air flow, spektrofotometer (evolution 201), pHmeter (martini instruments), timbangan analitik (Shimadzu AUX220), mikroskop (Olympus CX21FS1), pipet mikro (Finnpipette), pipet volume, labu ukur, erlenmeyer (pyrex), kertas saring, autoklaf, magnetic stirrer, waterbath (nvc thermologic), bunsen, tip $100 \mu \mathrm{L}$, tip $1000 \mu \mathrm{L}$, 
vortex, gelas objek, microtube, sentrifugasi, gelas ukur, batang bengkok, dan labu ukur.

\section{Pelaksanaan Penelitian \\ Penyegaran dan Konfirmasi Isolat}

Penyegaran bakteri L. rhamnosus SKG34 dilakukan dengan cara diambil $100 \mu \mathrm{L}$ stok isolat yang disimpan dalam gliserol $30 \%$ pada suhu $-20^{\circ} \mathrm{C}$ dan diinokulasi ke dalam tabung reaksi yang berisi $5 \mathrm{ml}$ media MRSB diinkubasi selama 24 jam dengan suhu $37^{\circ} \mathrm{C}$. Konfirmasi isolat meliputi uji pewarnaan gram, uji katalase, dan uji gas (Suryani et al., 2010).

Setelah penyegaran bakteri, dilakukan konfirmasi isolat melalui uji katalase, pewarnaan gram dan uji gas. Uji katalase dilakukan dengan dibuat tetesan isolat pada gelas objek, kemudian ditetesi dengan dua tetes larutan $\mathrm{H}_{2} \mathrm{O}_{2}$, dan diamati gelembung yang timbul. Hasil positif ditunjukkan oleh timbulnya gelembung udara $\left(\mathrm{O}_{2}\right)$ yang dihasilkan dari degradasi $\mathrm{H}_{2} \mathrm{O}_{2}$ oleh enzimenzim katalase (Suryani et al., 2010).

Pewarnaan gram dilakukan dengan meneteskan isolat pada gelas objek kemudian difiksasi di atas bunsen dan diwarnai dengan kristal violet selama 1 menit, kemudian ditetesi dengan larutan lugol selama 1 menit. Selanjutnya gelas objek ditetesi alkohol selama 1 menit dan terakhir diwarnai dengan pewarna safranin selama 5 detik. Sel bakteri yang telah diwarnai, dikeringkan dan diamati dibawah mikroskop (Suryani et al., 2010). Hasil positif ditunjukan oleh warna ungu yang berarti bahwa bakteri ini termasuk gram positif, hal ini dikarenakan bakteri tersebut memiliki kandungan lipid yang rendah, sehingga dinding sel bakteri akan lebih mudah terdehidrasi akibat perlakuan dengan alkohol yang menyebabkan ukuran pori-pori sel menjadi lebih kecil dan daya permeabilitasnya berkurang sehingga zat warna kristal violet yang merupakan zat warna utama tidak dapat keluar dari sel (Pelczar, 1986).
Uji gas dilakukan dengan metode hot loop, dengan cara memasukkan jarum ose panas ke dalam suspensi biakan BAL. Hasil positif ditandai oleh terbentuknya gas $\mathrm{CO}_{2}$ dari hasil metabolisme glukosa (Suryani et al., 2010).

\section{Pembuatan Sari Buah Terung Belanda}

Buah terung belanda disortasi terlebih dahulu dengan dipilih buah yang sudah matang dan berwarna merah. Setelah itu, buah dicuci hingga bersih. Buah dipotong secara vertikal menjadi dua bagian. Bagian daging buah dipisahkan dari kulitnya. Daging buah dihancurkan dengan menggunakan juicer extractor, lalu sari buah yang dihasilkan ditambahkan air dengan perbandingan sari buah dan air 1:2. Penyaringan pada sari buah dengan menggunakan dua lapis kain saring sehingga dihasilkan sari buah tanpa ampas. (Diniyah et al., 2013).

\section{Pembuatan Starter Sari Buah}

Persiapan starter sari buah terung belanda diawali dengan pembuatan substrat bakteri L. rhamnosus SKG34, yaitu sari buah terung belanda yang diambil dari stok sari buah terung belanda sebanyak $100 \mathrm{ml}$ ke dalam jar steril, kemudian ditambahkan sukrosa dengan konsentrasi 5\%. Sari buah terung belanda dipasteurisasi pada suhu $80^{\circ} \mathrm{C}$ selama 4,5 menit, lalu didiamkan sampai suhu mencapai $37^{\circ} \mathrm{C}$. Persiapan selanjutnya menumbuhkan stok kultur L. rhamnosus SKG34 yang diambil sebanyak $100 \mu \mathrm{l}$ dalam gliserol yang disimpan di freezer, lalu dimasukkan ke dalam $5 \mathrm{ml}$ media MRSB, lalu diinkubasi selama 24 jam pada $37^{\circ} \mathrm{C}$. Setelah inkubasi, media tersebut diamati, setelah hasil positif ditunjukkan dengan kekeruhan pada media, tabung reaksi tersebut kemudian divorteks dan diambil sebanyak $1 \mathrm{ml}$, kemudian dipindahkan ke dalam microtube untuk disentrifugasi pada kecepatan $5000 \mathrm{rpm}$ selama 10 menit hingga terbentuk endapan kultur mikroba pada dasar microtube. Supernatan di atas endapan kultur tersebut 
dibuang, sedangkan sel yang tertinggal dicuci sebanyak 3 kali. Pencucian sel dilakukan dengan cara menambahkan larutan saline ke dalam microtube berisi endapan kultur $L$. rhamnosus SKG34 lalu divorteks, selanjutnya microtube disentrifugasi pada kecepatan 5000 rpm selama 10 menit, dan membuang supernatan yang terbentuk setelah proses sentrifugasi. Larutan saline sisa dari pencucian terakhir dibuang, kemudian diambil sebanyak $1 \mathrm{ml}$ dari $100 \mathrm{ml}$ substrat sari buah terung belanda dan dimasukkan ke dalam microtube. Microtube tersebut divorteks dan kultur dalam microtube dimasukkan kembali dalam sari buah hingga mencapai volume $100 \mathrm{ml}$ kemudian diaduk. Substrat sari buah tersebut difermentasi selama 24 jam pada suhu $37^{\circ} \mathrm{C}$ (Ding dan Shah, 2008).

\section{Pembuatan Sari Buah Terung Belanda Probiotik Terfermentasi}

Sari buah terung belanda dimasukkan ke dalam jar sebanyak $96 \mathrm{ml}$ dan ditambahkan sukrosa sesuai dengan perlakuan $(0 \%, 3 \%$, $6 \%$, 9\%, dan 12\%). Sari buah dipasteurisasi dengan suhu $80^{\circ} \mathrm{C}$ selama 4,5 menit dengan menggunakan waterbath dimana proses ini bertujuan untuk menghentikan aktivitas mikroba maupun enzimatik pada sari buah, selanjutnya sari buah didiamkan hingga suhu mencapai $37^{\circ} \mathrm{C}$. Starter dimasukkan ke dalam jar yang berisi sari buah terung belanda sebanyak $4 \%$ pada masing-masing perlakuan, kemudian diaduk, dan sari buah terung belanda difermentasi selama 24 jam pada suhu $37^{\circ} \mathrm{C}$ (Diniyah et al., 2013). Formula sari buah terung belanda terfermentasi dapat dilihat pada Tabel 1.
Tabel 1. Formula sari buah terung belanda terfermentasi

\begin{tabular}{|c|c|c|c|}
\hline $\begin{array}{c}\text { Konsentrasi } \\
\text { Sukrosa (\%) }\end{array}$ & $\begin{array}{c}\text { Sari } \\
\text { buah } \\
(\mathrm{ml})\end{array}$ & $\begin{array}{c}\text { Sukrosa } \\
(\mathrm{g})\end{array}$ & $\begin{array}{c}\text { Starter } \\
(\%)\end{array}$ \\
\hline 0 & 96 & 0 & 4 \\
\hline 3 & 96 & 3 & 4 \\
\hline 6 & 96 & 6 & 4 \\
\hline 9 & 96 & 9 & 4 \\
\hline 12 & 96 & 12 & 4 \\
\hline
\end{tabular}

Keterangan : Tiap perlakuan ditambahkan $4 \%$ starter dalam $100 \mathrm{ml}$ produk.

\section{Rancangan Penelitian dan Analisis Data}

Penelitian ini menggunakan

Rancangan Acak Kelompok (RAK) dengan perlakuan konsentrasi sukrosa yang terdiri dari 5 taraf perlakuan, yaitu S0 (Sukrosa 0\%), S1 (Sukrosa 3\%), S2 (Sukrosa 6\%), S3 (Sukrosa 9\%), S4 (Sukrosa 12\%). Masingmasing perlakuan diulang sebanyak 3 kali sehingga diperoleh 15 unit percobaan. Data yang diperoleh kemudian dianalisis dengan Analysis of Variance (ANOVA) dan apabila terdapat pengaruh antara perlakuan dilanjutkan dengan Uji DNMRT New Multiple Range Test (DNMRT) (Gomez dan Gomez, 1995).

\section{Parameter yang Diamati}

Parameter yang diamati adalah total BAL dengan metode hitungan cawan (Fardiaz, 1992), total gula dengan metode Anthrone (Andarwulan et al., 2011), total asam dengan metode titrasi (Sudarmadji et al., 2007), $\mathrm{pH}$ dengan $\mathrm{pH}$ meter (AOAC, 1995), dan evaluasi sensoris meliputi uji hedonik terhadap warna, aroma, rasa, dan penerimaan secara keseluruhan, sedangkan uji skoring dilakukan terhadap warna, rasa asam, dan rasa manis (Soekarto, 1985).

\section{HASIL DAN PEMBAHASAN}

Hasil analisis total BAL, total gula, total asam, dan derajat keasaman $(\mathrm{pH})$ 
Tabel 2. Nilai rata-rata total BAL, total gula, total asam, dan $\mathrm{pH}$ minuman probiotik sari buah terung belanda terfermentasi

\begin{tabular}{ccccc}
\hline $\begin{array}{c}\text { Konsentrasi } \\
\text { Sukrosa }(\%)\end{array}$ & $\begin{array}{c}\text { Total BAL } \\
(\mathrm{cfu} / \mathrm{ml})\end{array}$ & Total Gula (\%) & Total Asam (\%) & $\mathrm{pH}$ \\
\hline 0 & $5,40 \times 10^{7} \mathrm{c}$ & $4,15 \pm 0,98 \mathrm{~d}$ & $2,91 \pm 0,17 \mathrm{~b}$ & $3,65 \pm 0,03 \mathrm{a}$ \\
3 & $1,03 \times 10^{8} \mathrm{bc}$ & $6,47 \pm 0,55 \mathrm{~d}$ & $3,03 \pm 0,26 \mathrm{a}$ & $3,64 \pm 0,03 \mathrm{ab}$ \\
6 & $2,67 \times 10^{8} \mathrm{ab}$ & $9,47 \pm 1,95 \mathrm{c}$ & $3,08 \pm 0,17 \mathrm{a}$ & $3,63 \pm 0,02 \mathrm{~b}$ \\
9 & $1,30 \times 10^{9} \mathrm{a}$ & $12,69 \pm 2,11 \mathrm{~b}$ & $3,08 \pm 0,17 \mathrm{a}$ & $3,61 \pm 0,03 \mathrm{c}$ \\
12 & $3,05 \times 10^{8} \mathrm{ab}$ & $15,39 \pm 2,84 \mathrm{a}$ & $2,86 \pm 0,26 \mathrm{~b}$ & $3,60 \pm 0,02 \mathrm{c}$ \\
\hline
\end{tabular}

Keterangan: Huruf yang sama di belakang nilai rata-rata pada kolom yang sama menunjukkan berbeda tidak nyata $(\mathrm{P}>0,05)$.

minuman probiotik sari buah terung belanda terfermentasi dapat dilihat pada Tabel 2.

\section{Total BAL}

Hasil sidik ragam menunjukkan bahwa perlakuan konsentrasi sukrosa berpengaruh nyata $(\mathrm{P}<0,05)$ terhadap total BAL pada minuman probiotik sari buah terung belanda terfermentasi. Nilai rata-rata total BAL berkisar antara $5,40 \times 10^{7} \mathrm{cfu} / \mathrm{ml}$ sampai $1,30 \times 10^{9} \mathrm{cfu} / \mathrm{ml}$. Nilai total BAL yang terendah terdapat pada perlakuan sukrosa $0 \%$, sedangkan nilai total BAL yang tertinggi terdapat pada perlakuan sukrosa $9 \%$. Perlakuan sukrosa $9 \%$ berbeda tidak nyata dengan perlakuan sukrosa $6 \%$ dan $12 \%$, tetapi berbeda nyata dengan perlakuan sukrosa $0 \%$ dan $3 \%$.

Total BAL sari buah terung belanda sebelum difermentasi, yaitu 4,00 x $10^{6} \mathrm{cfu} / \mathrm{ml}$. Setelah difermentasi selama 24 jam, total BAL meningkat dari $5,40 \times 10^{7} \mathrm{cfu} / \mathrm{ml}$ sampai $1,30 \times 10^{9} \mathrm{cfu} / \mathrm{ml}$. Tabel 2 menunjukkan peningkatan total BAL hingga perlakuan sukrosa $6 \%$ menjadi $2,67 \times 10^{8} \mathrm{cfu} / \mathrm{ml}$, serta total BAL yang berbeda tidak nyata dari perlakuan sukrosa $6 \%$ sampai $12 \%$. Penambahan konsentrasi sukrosa hingga $6 \%$ menunjukkan peningkatkan pertumbuhan BAL pada minuman probiotik sari buah terung belanda terfermentasi, namun setelah penambahan sukrosa melebihi $6 \%$ dihasilkan total BAL yang tetap (konstan). Peningkatan total BAL hingga konsentrasi $6 \%$ disebabkan karena nutrisi BAL terpenuhi sehingga membantu pertumbuhan dan metabolisme BAL selama proses fermentasi.

Total BAL yang berbeda tidak nyata dari perlakuan sukrosa $6 \%$ hingga $12 \%$ dikarenakan BAL sudah memanfaatkan sukrosa secara optimal dan telah memasuki fase stasioner (jumlah yang seimbang antara bakteri yang hidup dan yang mati). Hal ini disebabkan karena tingginya konsentrasi substrat akan menurunkan jumlah bakteri dan produksi bakteriosin, penghambatan ini disebabkan karena adanya represi katabolik, serta terjadinya plasmolisis sel. Pada metabolisme BAL homofermentatif, sukrosa harus diinvers terlebih dahulu dengan enzim $\beta$-fructofuranosidase menjadi glukosa dan fruktosa, kemudian glukosa langsung dapat dimetabolisme menjadi asam laktat melalui glikosis. Pada fase stasioner akan terjadi penumpukan metabolit hasil aktivitas metabolisme sel, yaitu asam laktat yang dapat menghambat pertumbuhan sel BAL (Yuliana, 2008; Yeni, et al., 2016). Total BAL dari semua perlakuan kosentrasi sukrosa pada minuman probiotik sari buah terung belanda terfermentasi sudah memenuhi standar SNI7522-2009 tentang syarat mutu minuman susu fermentasi berperisa, yaitu sebesar $10^{6} \mathrm{cfu} / \mathrm{ml}$ yang Tammie, et al. (2006) menyatakan bahwa produk probiotik harus memiliki jumlah sel hidup, yaitu $10^{7}$ sampai $10^{9}$ 
cfu/ml agar memberi efek positif pada kesehatan.

\section{Total Gula}

Hasil sidik ragam menunjukkan bahwa perlakuan konsentrasi sukrosa berpengaruh nyata $(\mathrm{P}<0.05)$ terhadap total gula pada minuman probiotik sari buah terung belanda terfermentasi. Nilai rata-rata total gula berkisar antara 4,15\% sampai $15,39 \%$. Nilai total gula terendah terdapat pada perlakuan konsentrasi sukrosa $0 \%$, sedangkan nilai total gula tertinggi terdapat pada perlakuan sukrosa $12 \%$. Perlakuan $12 \%$ berbeda nyata dengan perlakuan $0 \%, 3 \%, 6 \%$, $9 \%$. Perlakuan $0 \%$ berbeda tidak nyata dengan perlakuan $3 \%$, namun berbeda nyata dengan perlakuan $6 \%, 9 \%$, dan $12 \%$.

Tabel 2 menunjukkan peningkatan total gula dari $4,15 \%$ menjadi $15,39 \%$ pada perlakuan sukrosa $0 \%$ hingga $12 \%$. Hal ini menunjukkan bahwa peningkatan total gula seiring dengan perlakuan sukrosa yang ditambahkan ke dalam minuman probiotik sari buah terung belanda terfermentasi. Total gula sari buah terung belanda sebelum difermentasi adalah $7,64 \%$. Selama proses fermentasi, sukrosa pada minuman probiotik sari buah terung belanda terfermentasi mengalami hidrolisis menjadi glukosa dan fruktosa yang akan dimetabolisme oleh BAL. Sukrosa yang ditambahkan pada perlakuan 0\% dan 3\% sudah mampu dimanfaatkan oleh BAL secara optimal. BAL memiliki batasan optimal untuk memanfaatkan gula sebagai sumber energi sehingga tidak semua gula yang terkandung dalam produk dapat difermentasi menjadi asam laktat. Akibatnya jumlah gula yang tersisa akan mengalami peningkatan seiring dengan bertambahnya jumlah gula yang ditambahkan ke dalam produk (Sintasari et al., 2014).

\section{Total Asam}

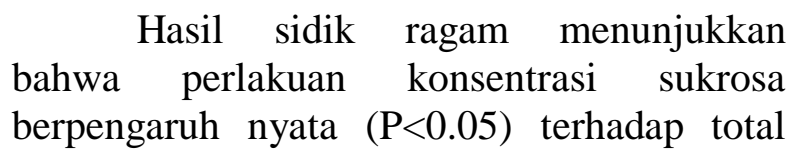

asam pada minuman probiotik sari buah terung belanda terfermentasi. Nilai rata-rata total asam berkisar antara $2,86 \%$ sampai $3,08 \%$. Nilai total asam terendah terdapat pada perlakuan konsentrasi sukrosa $12 \%$, sedangkan nilai total asam tertinggi terdapat pada perlakuan sukrosa $6 \%$ dan $9 \%$. Perlakuan sukrosa $9 \%$ berbeda tidak nyata dengan perlakuan $3 \%$ dan $6 \%$, namun berbeda nyata dengan perlakuan sukrosa $0 \%$ dan $12 \%$.

Tabel 2 menunjukkan bahwa total asam pada konsentrasi sukrosa $0 \%$ meningkat hingga $6 \%$ dan $9 \%$, yaitu dari $2,91 \%$ menjadi $3,08 \%$, namun pada konsentrasi sukrosa $12 \%$ mengalami penurunan menjadi $2,86 \%$. Hal ini disebabkan karena semakin banyak sukrosa yang ditambahkan akan meningkatkan jumlah BAL sehingga total asam akan semakin meningkat, tetapi pada perlakuan sukrosa $12 \%$ terjadi penurunan yang diduga karena menurunnya kemampuan BAL dalam memproduksi asam laktat akibat penambahan sukrosa yang melebihi kebutuhan nutrisi BAL. Sukrosa selama proses fermentasi akan dipecah menjadi monosakarida dimana monosakarida akan dimetabolisme oleh BAL melalui glikolisis yang pada akhirnya dihasilkan asam laktat (Yeni, et al., 2016). Hal tersebut sesuai dengan Kumalasari et al. (2012) yang menyatakan bahwa total asam dipengaruhi oleh aktivitas BAL karena asam yang terkandung merupakan hasil metabolit dari BAL tersebut. Penambahan sukrosa yang melebihi kebutuhan nutrisi BAL dapat menyebabkan kondisi lingkungan menjadi hipertonik sehingga mengakibatkan terjadinya plasmolisis sel BAL yang diduga dapat menurunkan kemampuannya dalam memproduksi asam laktat (Tammie et al., 2006).

\section{Derajat Keasaman (pH)}

$\begin{array}{rrr}\text { Hasil sidik } & \text { ragam menunjukkan } \\ \text { bahwa perlakuan } & \text { konsentrasi sukrosa }\end{array}$ berpengaruh nyata $(\mathrm{P}<0,05)$ terhadap $\mathrm{pH}$ pada minuman probiotik sari buah terung belanda terfermentasi. Nilai rata-rata $\mathrm{pH}$ berkisar 
Tabel 3. Nilai rata-rata evaluasi sensoris minuman probiotik sari buah terung belanda terfermentasi

\begin{tabular}{|c|c|c|c|c|c|c|c|}
\hline \multirow[b]{2}{*}{$\begin{array}{l}\text { Perlakuan } \\
\quad(\%)\end{array}$} & \multicolumn{3}{|c|}{ Hedonik } & \multicolumn{3}{|c|}{ Skor } & \multirow{2}{*}{$\begin{array}{l}\text { Penerimaan } \\
\text { Keseluruhan }\end{array}$} \\
\hline & Warna & Aroma & Rasa & Warna & $\begin{array}{l}\text { Rasa } \\
\text { Asam }\end{array}$ & $\begin{array}{c}\text { Rasa } \\
\text { Manis }\end{array}$ & \\
\hline 0 & $5,40 \mathrm{a}$ & $5,00 \mathrm{a}$ & $3,60 \mathrm{c}$ & $2,70 \mathrm{~b}$ & $3,50 \mathrm{a}$ & $1,20 \mathrm{c}$ & $3,95 \mathrm{c}$ \\
\hline 3 & $5,60 \mathrm{a}$ & $4,90 \mathrm{a}$ & $3,70 \mathrm{c}$ & $3,10 \mathrm{a}$ & $3,30 \mathrm{a}$ & $1,35 \mathrm{c}$ & $4,45 b$ \\
\hline 6 & $5,75 \mathrm{a}$ & $5,25 \mathrm{a}$ & $4,75 \mathrm{~b}$ & $2,95 \mathrm{ab}$ & $2,60 \mathrm{~b}$ & $1,90 \mathrm{~b}$ & $4,85 \mathrm{~b}$ \\
\hline 9 & $5,80 \mathrm{a}$ & $5,30 \mathrm{a}$ & $5,15 \mathrm{ab}$ & $3,20 \mathrm{a}$ & $2,30 \mathrm{c}$ & $2,60 \mathrm{a}$ & $5,50 \mathrm{a}$ \\
\hline 12 & $5,40 \mathrm{a}$ & $5,20 \mathrm{a}$ & $5,50 \mathrm{a}$ & $3,00 \mathrm{ab}$ & $1,95 \mathrm{c}$ & $2,80 \mathrm{a}$ & $5,45 \mathrm{a}$ \\
\hline
\end{tabular}

Keterangan: Huruf yang sama di belakang nilai rata-rata pada kolom yang sama menunjukkan berbeda tidak nyata $(\mathrm{P}>0,05)$.

Kriteria hedonik $\quad: 7=$ sangat suka, $6=$ suka, $5=$ agak suka, $4=$ biasa,

3 = agak tidak suka, 2 = tidak suka, $1=$ sangat tidak suka.

Kriteria skor warna $\quad: 1=$ kuning, $2=$ jingga, $3=$ merah, $4=$ merah tua.

Kriteria skor rasa asam : $1=$ tidak asam, $2=$ agak asam, $3=$ asam, $4=$ sangat asam.

Kriteria skor rasa manis : $1=$ tidak manis, $2=$ agak manis, $3=$ manis, $4=$ sangat manis.

antara 3,60 sampai 3,65. Nilai $\mathrm{pH}$ terendah terdapat pada perlakuan konsentrasi sukrosa $12 \%$, sedangkan nilai $\mathrm{pH}$ tertinggi terdapat pada perlakuan sukrosa 0\%. Perlakuan $0 \%$ berbeda tidak nyata dengan perlakuan 3\%, namun berbeda nyata dengan perlakuan $6 \%$, $9 \%$ dan $12 \%$. Tabel 2 menunjukkan penurunan $\mathrm{pH}$ seiring dengan meningkatnya total asam yang dihasilkan pada minuman probiotik sari buah terung belanda terfermentasi. Nilai $\mathrm{pH}$ dengan perlakuan sukrosa $0 \%$ hingga $12 \%$ mengalami penurunan dari 3,65 menjadi 3,60. Semakin banyak sukrosa yang ditambahkan, maka jumlah BAL akan semakin meningkat sehingga total asam akan semakin meningkat dan $\mathrm{pH}$ semakin menurun. Hal ini disebabkan karena penurunan $\mathrm{pH}$ sejalan dengan total asam. Sukrosa dirombak oleh BAL homofermetatif menjadi asam laktat sebagai produk utama. Asam laktat yang dihasilkan tersebut akan disekresikan keluar sel dan terdisosiasi sehingga ion $\mathrm{H}^{+}$yang terbebaskan dalam medium dan menyebabkan menurunnya $\mathrm{pH}$ (Khotimah dan Kusnadi, 2014). Sukrosa juga dimanfaatkan oleh BAL sebagai energi penunjang pertumbuhannya yang dirombak menjadi asam laktat sehingga dapat menurunkan $\mathrm{pH}$ minuman probiotik jambu biji merah (Ganzle and Follador, 2012).

\section{Evaluasi Sensoris}

Nilai rata-rata uji hedonik terhadap warna, aroma, rasa dan penerimaan keseluruhan, serta nilai rata-rata uji skoring terhadap warna, rasa asam dan rasa manis dapat dilihat pada Tabel 3.

\section{Warna}

$\begin{array}{rlr}\text { Hasil sidik } & \text { ragam menunjukkan } \\ \text { bahwa perlakuan } & \text { konsentrasi sukrosa }\end{array}$ berpengaruh tidak nyata $(\mathrm{P}>0,05)$ terhadap hedonik warna, tetapi berpengaruh nyata $(\mathrm{P}<0,05)$ terhadap skor warna pada minuman probiotik sari buah terung belanda terfermentasi. Tabel 3 menunjukkan hasil penilaian uji hedonik terhadap warna oleh panelis berkisar antara 5,40 sampai 5,80 (agak suka sampai suka). Penilaian berdasarkan uji skoring terhadap warna berkisar antara 2,70 sampai 3,20 (merah). Perlakuan sukrosa 9\% berbeda tidak nyata dengan perlakuan sukrosa $3 \%$, $6 \%$, dan $12 \%$, tetapi berbeda nyata dengan perlakuan $0 \%$. Warna merupakan karakteristik utama dari sebuah produk dimana menjadi kesan pertama yang diterima konsumen terhadap suatu produk. 
Warna dipengaruhi oleh komponen penyusun dalam bahan dimana warna daging buah terung belanda adalah merah (Winarno, 2004).

\section{Aroma}

Hasil sidik ragam menunjukkan bahwa perlakuan konsentrasi sukrosa tidak berpengaruh nyata $(\mathrm{P}>0,05)$ terhadap aroma pada minuman probiotik sari buah terung belanda terfermentasi. Tabel 3 menunjukkan hasil penilaian uji hedonik terhadap aroma oleh panelis berkisar antara 4,90 sampai 5,30 (agak suka).

\section{Rasa}

Hasil sidik ragam menunjukkan berpengaruh nyata $(\mathrm{P}<0,05)$ terhadap hedonik rasa, skor rasa asam, dan skor rasa manis pada minuman probiotik sari buah terung belanda terfermentasi.

Tabel 3 menunjukkan hasil penilaian uji hedonik oleh panelis terhadap rasa berkisar antara 3,60 - 5,50 (biasa sampai suka). Nilai kesukaan rasa tertinggi terdapat pada perlakuan sukrosa $12 \%$ dengan kriteria suka, sedangkan nilai kesukaan rasa terendah terdapat pada perlakuan sukrosa $0 \%$ dengan kriteria biasa. Perlakuan sukrosa $12 \%$ berbeda tidak nyata dengan perlakuan sukrosa $9 \%$, tetapi berbeda nyata dengan perlakuan sukrosa $0 \%, 3 \%$ dan 6\%. Penilaian berdasarkan uji skoring terhadap rasa asam berkisar antara 1,95 - 3,50 (agak asam sampai sangat asam), sedangkan uji skoring terhadap rasa manis berkisar antara 1,20 - 2,80 (tidak manis sampai manis). Nilai skor rasa asam tertinggi terdapat pada perlakuan sukrosa $0 \%$, sedangkan nilai skor rasa asam terendah terdapat pada perlakuan sukrosa $12 \%$. Perlakuan sukrosa $0 \%$ berbeda tidak nyata dengan perlakuan sukrosa $3 \%$, tetapi berbeda nyata dengan perlakuan sukrosa $6 \%, 9 \%$, dan $12 \%$. Nilai skor rasa manis tertinggi terdapat pada perlakuan sukrosa $12 \%$, sedangkan nilai skor rasa manis terendah terdapat pada perlakuan sukrosa 0\%. Perlakuan sukrosa $12 \%$ berbeda tidak nyata dengan perlakuan sukrosa $9 \%$, tetapi berbeda nyata dengan perlakuan sukrosa $0 \%, 3 \%$, dan $6 \%$.

Panelis menyukai rasa agak asam dan manis pada minuman probiotik sari buah terung belanda. Rasa asam dihasilkan dari asam laktat, sedangkan rasa manis dari sukrosa. Semakin tinggi konsentrasi sukrosa yang ditambahkan pada minuman probiotik sari buah terung belanda terfermentasi akan menyebabkan rasa manis sehingga lebih disukai oleh panelis. Hal ini mengakibatkan rasa produk tidak terlalu asam dan cenderung manis.

\section{Penerimaan Keseluruhan}

Hasil sidik ragam menunjukkan bahwa penambahan sukrosa berpengaruh nyata $\quad(\mathrm{P}<0,05) \quad$ terhadap penerimaan keseluruhan dari minuman probiotik sari buah terung belanda terfermentasi. Tabel 3 menunjukkan hasil uji hedonik oleh panelis terhadap penerimaan keseluruhan berkisar antara 3,95 sampai 5,50 (biasa sampai suka). Nilai penerimaan keseluruhan terendah terdapat pada perlakuan sukrosa $0 \%$, sedangkan nilai penerimaan keseluruhan tertinggi terdapat pada perlakuan sukrosa $9 \%$. Perlakuan sukrosa $9 \%$ berbeda tidak nyata dengan perlakuan sukrosa $12 \%$, tetapi berbeda nyata dengan perlakuan sukrosa $0 \%$, $3 \%$ dan 6\%. Semakin tinggi sukrosa yang ditambahkan tingkat kesukaan panelis cenderung semakin meningkat.

\section{Perlakuan Terbaik}

Penentuan perlakuan terbaik minuman probiotik sari buah terung belanda terfermentasi pada penelitian ini berdasarkan analisis yang telah dilakukan meliputi total BAL, total asam, $\mathrm{pH}$, serta evaluasi sensoris produk yang dihasilkan dengan uji hedonik terhadap warna, aroma, rasa, dan penerimaan keseluruhan. Penentuan perlakuan terbaik pada penelitian ini terdiri dari dua tahap. 
Tahap pertama, pemilihan perlakuan yang memiliki total BAL $\left(>1 \times 10^{6} \mathrm{cfu} / \mathrm{ml}\right)$ sesuai standar SNI 7552:2009, total asam $(>0,45 \%)$ sesuai standar SNI 01-3719-2014, serta $\mathrm{pH} 3-6$ dimana pada rentang $\mathrm{pH}$ tersebut bakteri L. rhamnosus SKG34 masih dapat aktif dan bertumbuh dengan baik. Hasil pemilihan tahap pertama diperoleh semua perlakuan dapat menjadi perlakuan terbaik. Selanjutnya diseleksi pada tahap kedua, yaitu evaluasi sensoris dengan dengan uji hedonik, parameter sifat sensoris yang diamati adalah warna, aroma, rasa, dan penerimaan keseluruhan. Hasil uji hedonik menunjukkan bahwa penerimaan keseluruhan tertinggi terdapat pada perlakuan 9\% dan $12 \%$. Perlakuan sukrosa $9 \%$ dengan $12 \%$ berbeda tidak nyata sehingga perlakuan terbaik yang dipilih yang lebih efesien, yaitu perlakuan sukrosa 9\%. Minuman probiotik sari buah terung belanda terfermentasi pada perlakuan sukrosa 9\% menghasilkan minuman probiotik dengan karakteristik terbaik, yaitu total BAL $1,30 \times 10^{9} \mathrm{cfu} / \mathrm{ml}$, total gula $12,69 \%$, total asam 3,08\%, $\mathrm{pH} 3,61$, hedonik warna yang disukai $(5,80)$, skor warna merah $(3,20)$, aroma yang biasa $(5,30)$, rasa hedonik yang agak disukai $(5,15)$, rasa yang agak asam $(2,30)$ dan manis $(2,60)$, dan penerimaan keseluruhan yang disukai $(5,50)$.

\section{KESIMPULAN DAN SARAN}

\section{Kesimpulan}

1. Perlakuan konsentrasi sukrosa pada pada minuman probiotik sari buah terung belanda terfermentasi berpengaruh terhadap total BAL, total gula, total asam, $\mathrm{pH}$, warna (skoring), rasa (hedonik), rasa asam dan rasa manis (skoring), dan penerimaan keseluruhan, tetapi tidak berpengaruh terhadap warna (hedonik) dan aroma.

2. Konsentrasi sukrosa $9 \%$ menghasilkan minuman probiotik sari buah terung belanda terfermentasi dengan karakteristik terbaik, yaitu total BAL $1,30 \times 10^{9} \mathrm{cfu} / \mathrm{ml}$, total gula $12,69 \%$, total asam 3,08\%, pH 3,61, hedonik warna yang disukai $(5,80)$, skor warna merah $(3,20)$, aroma yang biasa $(5,30)$, rasa hedonik yang agak disukai $(5,15)$, rasa yang agak asam $(2,30)$ dan manis $(2,60)$, dan penerimaan keseluruhan yang disukai $(5,50)$.

\section{Saran}

Berdasarkan hasil penelitian, disarankan menggunakan konsentrasi sukrosa 9\% dalam pembuatan minuman probiotik sari buah terung belanda terfermentasi untuk memperoleh karakteristik terbaik. Perlu dilakukan penelitian lebih lanjut mengenai lama penyimpanan minuman probiotik sari buah terung belanda terfermentasi dengan $L$. rhamnosus SKG34 dengan penambahan sukrosa $9 \%$ pada penyimpanan dingin.

\section{DAFTAR PUSTAKA}

Andarwulan, N., F. Kusnandar, dan D. Herawati. 2011. Analisis Pangan. Dian Rakyat, Jakarta.

Anonimous. 2009. SNI-7522-2009 tentang Minuman Susu Fermentasi Berperisa. Badan Standardisasi Nasional, Jakarta.

Anonimous. 2014. Minuman Sari Buah. Standar Nasional Indonesia (SNI):SNI01-3719-2014. Badan Standardisasi Nasional, Jakarta.

AOAC. 1995. Official Methods of Analysis. 16th Edition. Association of Official Analytical Chemists, Washington DC.

Ding, W.K. dan N.P. Shah. 2008. Survival of free and microencapsulated probiotic bacteria in orange and apple juices. International Food Journal 15(2):219232. 
Diniyah, N., A. Subagio, dan M. Fauzi. 2013. Produksi minuman fungsional sirsak (Anonna muricata Linn) dengan fermentasi bakteri asam laktat. Jurnal Teknotan 2(7):1007-1012.

Elsaputra, U. Pato, dan Rahmayuni. 2016. Pembuatan minuman probiotik berbasis kulit nanas (Ananas comosus (l.) Merr.) menggunakan Lactobacillus casei subsp. casei R-68 yang diisolasi dari dadih. J. Faperta 3(1).

Fardiaz, S. 1992. Mikrobiologi Pangan I. Gramedia Pustaka Utama, Jakarta.

Food Agriculture Organization/World Health Organization (FAO/WHO). 2001. Guidelines for The Evaluation of Probiotics in Food. Report of a Joint FAO/WHO Working Group on Drafting Guidelines for The Evaluation of Probiotics in Food, Canada.

Fuller, R. 1989. A Review: Probiotics in man and animals. Journal of Applied Bacteriology. 66:365-378.

Ganzle, M.G., dan R. Follador. 2012. Metabolism of oligosaccharides and starch in Lactobacilli: a review. Frontiers in Microbiology 3(340):1-15.

Gomez, K.A., dan A.A. Gomez. 1995. Prosedur Statistik Untuk Penelitian Pertanian. ed. 2. UI-Press, Jakarta.

Harahap, N.O., S.J. Vonny, dan P. Usman. 2018. Pembuatan minuman fermentasi sari tomat dengan menggunakan Lactobacillus casei subsp. casei R-68. JOM UR. 5(2):1-12.
Hartati, K.F., Susanto, S. Rakhmadiono, dan L. Adi. 2002. Faktor-faktor yang berpengaruh terhadap tahap deproteinasi menggunakan enzim protease dalam pembuatan kitin dari cangkang rajungan (Portunus pelagius). Biosains 2(1):6877.

Khotimah, K. dan J. Kusnadi. 2014. Aktivitas antibakteri minuman probiotik sari kurma (Phoenix dactilyfera L.) menggunakan Lactobacillus plantarum dan Lactobacillus casei. Jurnal Pangan dan Agroindustri. 2(3):110-120.

Kumalaningsih, S. dan Suprayogi. 2006. Tamarillo (Terung Belanda) Tanaman Berkhasiat Penyedia Antioksidan Alami. Trubus Agrisarana, Surabaya.

Kumalasari, K.E.D., Nurwantoro, dan S. Mulyani. 2012. Pengaruh kombinasi susu dengan air kelapa terhadap total bakteri asam laktat (BAL), total gula dan keasaman drink yoghurt. Jurnal Aplikasi Teknologi Pangan 1(2): 4853.

Nurainy F., R. Samsul, S. Suharyono, dan U. Ekariza. 2018. Karakteristik minuman probiotik jambu biji (Psidium guajava) pada berbagai variasi penambahan sukrosa dan susu skim. Jurnal Aplikasi Teknologi Pangan. 7(2):47-54.

Pelczar, M.J. dan E.C.S. Chan. 1986. DasarDasar Mikrobiologi 1. (Eds.) R. Siri dan Hadioetomo. Universitas Indonesia Press, Jakarta.

Retnowati, P.A. dan K. Joni. 2014. Pembuatan minuman probiotik sari buah kurma (Phoenix dactylifera) dengan isolat Lactobacillus casei dan Lactobacillus plantarum. Jurnal Pangan dan Agroindustri. 2(2):70-81. 
Rini, A.P. 2019. Viabilitas Lactobacillus sp. F213 pada Berbagai Minuman Probiotik Sari Buah Selama Penyimpanan. Skripsi. Tidak dipublikasikan. Fakultas Teknologi Pertanian UNUD, Jimbaran.

Rizal S., E. Maria, N. Fibra, dan R.T. Artha. 2016. Karakteristik probiotik minuman fermentasi laktat sari buah nanas dengan variasi jenis bakteri asam laktat. Jurnal Kimia Terapan Indonesia. 18(1):63-71.

Sintasari, R.A., J. Kusnadi, D.W. Ningtyas. 2014. Pengaruh penambahan konsentrasi susu skim dan sukrosa terhadap karakterisik minuman probiotik sari beras merah. Jurnal Pangan dan Agroindustri. 2(3):65-75.

Soekarto, S.T. 1985. Penilaian Organoleptik (untuk Industri Pangan dan Hasil Pertanian). Penerbit Bharata Karya Aksara, Jakarta.

Sudarmadji S., B. Haryono, dan Suhardi. 2007. Prosedur Analisis Bahan Makanan dan Pertanian. Liberty, Yogyakarta.

Sujaya, N., N.M.U. Dwipayanti, N.L.P. Suariani, N.P. Widarini, K.A. Nocianitri, dan N.W. Nursini. 2008. Potensi Lactobacillus spp. isolat susu kuda sumbawa sebagai probiotik. J. Vet. 9(1):33-40.

Suryani, Yoni, A.B. Oktavia, dan S. Umniyati. 2010. Isolasi dan karakterisasi bakteri asam laktat dari limbah kotoran ayam sebagai agensi probiotik dan enzim kolesterol reduktase. Biota. 12(3):177-185.

Tammie, A.Y., L.E. Nilsson, and S. Lyck. 2006. Fermented milks. Oxford, Blackwell.
Yeni, A. Meryandini, dan T.C. Sunarti. 2016. Penggunaan substrat whey tahu untuk produksi biomassa oleh Pediococcus pentosaceus E.1222. Jurnal Teknologi Industri Pertanian. 26(3):284-293.

Yuliana, N. 2008. Kinetika pertumbuhan bakteri asam laktat isolat T5 yang berasal dari tempoyak. Jurnal Teknologi Industri dan Hasil Pertanian. 13(2):108-116.

Winarno, F.G. 2004. Kimia Pangan dan Gizi. Gramedia Pustaka Utama, Jakarta. 